\title{
Faktor Yang Mempengaruhi Penggunaan KB Suntik
}

\author{
Factors Affecting The Use of Injection KB \\ Wiwi Sartika1, Siti Qomariah, Nurmaliza \\ Program Studi D III Kebidanan Universitas Abdurrab \\ 1Email : wiwi.sartika@univrab.ac.id
}

\begin{abstract}
ABSTRAK
Percepatan pertumbuhan penduduk di dunia padatahun 2013 mengalami peningkatan lebih tinggi dari perkiraan. Jumlah penduduk dunia pada bulan Juli 2013 mencapai7,2 miliar jiwa, penduduk dunia akan naikmenjadi 8,1 miliar jiwa pada tahun 2025.Jumlah itu akan terus berkembang menjadi 9,6miliar pada tahun 2050. Tujuan ini bertujuan untuk mengidentifikasi faktor-faktor yang mempengaruhi prilaku aseptor KB untuk menggunakan alat kontrasepsi Suntik di Klinik Pratama Afiyah. Metode penelitian yang digunakan dalam penelitian ini adalah metode penelitian survey analitik dengan designcross sectional. Penelitian ini dilaksanakan pada tanggal 1s/d 31 Desember 2019 di Klinik Pratama Afiyah. Populasi seluruh ibu pengguna alat kontrasepsi yang berkunjung di Klinik pratama afiyah dan sampel sebanyak 57 orang. Tehnik penggunakan data menggunakan Accidental Sampling sampel diambil secara kebetulan. Instrument penelitian yang digunakan adalah berbentuk kuesioner. Prosedur pengolaan data dengan Editing, Coding, Processing, Cleaning. Analisis data dengan univariat dalam penelitian ini adalah variabel dependen dan independen yang dianalisa. Analisa Bivariat dengan menggunakan uji chi-square dengan tingkat kepercayaan 95\%. Hasil penelitian Pengetahuan .006, Pendidikan .006, Umur .012, Media Informasi .005, Ketersediaan Alat Kontrasepsi .000, Petugas Kesehatan .000, Dukungan Suami.000. Kesimpulan bebearpa faktor yang mempengaruhi: pengetahuan, umur, pendidikan, Dukunagn Suami, ketersediaan alat kontrasepsi, petugas kesehatan, Media Informasi.
\end{abstract}

Kata Kunci: Pemilihan, Metode, KB suntik

\section{ABSTRACT}

The acceleration of population growth in the world in 2013 increased higher than expected. The world population in July 2013 reached 7.2 billion people, the world population will increase to 8.1 billion people in 2025. That number will continue to grow to 9.6 billion in 2050. This objective aims to identify factors which influences the behavior of family planning acceptors to use injection contraceptives in the Pratama Afiyah Clinic. The research method used in this research was analytic survey research method with cross sectional design. The research was carried out on December 1 st 31 December 2019 at the Pratama Afiyah Clinic. The population of all mothers who use contraceptives visiting Pratama Afiyah Clinic and a sample of 57 people. The technique of using data using accidental sampling was taken by chance. The research instrument used was a questionnaire. Data processing procedures with Editing, Coding, Processing, Cleaning. Univariate data analysis in this study were the dependent and independent variables analyzed. Bivariate analysis using chi-square test with $95 \%$ confidence level. Knowledge research results .006, Education .006, Age .012, Media Information .005, Availability of Contraception .000 , Health Officers .000, Husband Support. Conclusion of several factors that influence: knowledge, age, education, husband support, availability of contraceptives, health workers, information media.

Keywords: Election, Method, KB injection

\section{PENDAHULUAN}

Percepatan pertumbuhan

penduduk di dunia padatahun 2013 mengalami peningkatan lebih tinggidari perkiraan. Jumlahpenduduk dunia pada bulan Juli 2013 mencapai7,2 miliar jiwa, penduduk dunia akan naikmenjadi 8,1 miliar jiwa pada tahun 2025.Jumlah itu akan terus berkembang menjadi 9,6miliar pada tahun 2050 . 
Salah satu cara yang digunakan untukmenekan lajupertumbuhan pendudukadalahmelalui pengendalian angka kelahiran. Pemerintah melalui Badan Kependudukan dan Keluarga Berenca na $(\mathrm{BKKBN})$ telah menerapka $\mathrm{n}$ program KB yang dimulai sejak tahun 1970 (BKKBN, 2012).

Program keluarga berencana memberikan kesempatanuntuk mengatur jarak kelahiran atau mengurangi jumlah kelahiran denganmenggunakan metode kontrasepsihormonal atau kontrasepsi nonhormonal. Upaya ini dapat bersifat sementara ataupun permanen, meskipun masing-masing jenis kontrasepsi memiliki tingkat efektifitas yang berbeda dan hampir sama (Gustikawati, 2014).

Angka pencapaian akseptor KB di Indonesia pada tahun 2011 dari 45.905.815 Pasangan Usia Subur (PUS) sebanyak 34.872.054(75,96\%) telah menjadi akseptor KB aktif. Jumlah akseptor KB jangka panjang seperti IUD hanya se besar $11,28 \%$, KB implant 8,82\%, MOW 3,49\%, dan jumlah akseptorKB terbanyak masihdidominasi akseptor KB suntikyaitu se besar 46, $47 \%$.

Kontrasepsi suntik merupakan salah satu metode kontrasepsi yang banyak digunakan di Indonesia.
Penggunaan kontrasepsi hormonal sebagai salah satu alat kontrasepsi meningkat drastis. Metode kontrasepsi yang memiliki efektifitas tinggi baik suntik 1 bulan maupun yang 3 bulan.

Pemilihan Kontrasepsi oleh wanita usia subur yang sesuai keinginan sangat penting, salah satu kontrasepsi yang banyakdipilih adalah KB suntikan baik 1 bulan mauun 3 bulan, karena suntik merupakan alat kontrasepsi yang praktis, aman,murah. Faktor yang mempengaruhi dalam menggunakan KB suntik, antara lain yaitu: Pengetahuan, Pendidikan, Umur, Media Informasi, Ketersediaan alat, Petugas Kesehatan, Dukungan Suami. (Astuti,2010).

Hasil penelitian dari Rendys Septalia dkk, 2016 dengan judul Faktor yang Memengaruhi Pemilihan Metode Kontrasepsi, Variabel yang diteliti terdiri dari variable independen yaitu biaya pemakaian kontrasepsi (anggapan akseptor KB mengenai mahal atau tidaknya biaya yang di tanggung dalam bentuk sejumlah uang yang harus dikeluarkan untuk mendapatkan pelayanan kontrasepsi), biaya non materiil (pengalaman efek samping), hambatan norma budaya, hambatan penyesuaian sosial, hambatan kesehatan fisik dan mental, hambatan aksesbilitas 
dan variabel dependen yaitu pemilihan metode kontrasepsi

Metode kontrasepsi hormonal pada dasarnya dibagi menjadi 2 yaitu kombinasi (mengandung hormon progesteron dan estrogen sintetik) dan yang hanya berisi progesteron saja. Kontrasepsi hormonal kombinasi terdapat pada pil dan suntikan/injeksi. Pada umumnya akseptor lebih memilih metode kontrasepsi suntik, karena alasan praktis yaitu sederhana dan tidak perlu takut lupa. Kontrasepsi suntik memiliki efektifitas yang tinggi bila penyuntikan dilakukan secara teratur dan sesuai jadwal yang telah ditentukan (Handayani, 2010)

Tujuan dari penelitian ini adalah untuk mengidentifikasi faktor-faktor yang mempengaruhi prilaku aseptor $\mathrm{KB}$ untuk menggunakan alat kontrasepsi Suntik di Klinik Pratama Afiyah Tahun 2019.

\section{METODE PENELITIAN}

Metode penelitian yang digunakan dalam penelitian ini adalah metode penelitian survey analitik dengan designcross sectional. Penelitian ini dilaksanakan pada tanggal 1s/d 31 Desember 2019 di Klinik Pratama Afiyah Pekanbaru. Populasi seluruh ibu pengguna alat kontrasepsi yang berkunjung di klinik pratama afiyah Pekanbaru dan sampel sebanyak 57orang yang menggunakan KB suntik 3 bulan. Tehnik penggunakan data dengan menggunakan Accidental Sampling dimana sampel diambil secara kebetulan sebagai responden. Instrument penelitian yang digunakan adalah berbentuk kuesioner. Prosedur pengolaan data dengan Editing, Coding, Processing, Cleaning. Analisis data dengan univariat dalam penelitian ini adalah variabel dependen dan independen yang dianalisa. Analisa Bivariat dengan menggunakan uji chi-square dengan tingkat kepercayaan $95 \% \quad(\alpha \leq 0,05)$ (Sugiyono,2017).

\section{HASIL DAN PEMBAHSAN}

\section{A. Karakteristik Responden}

Dalam penelitian ini adalah seluruh ibu pengguna aseptor $\mathrm{KB}$ suntik berkunjungdi Klinik Pratama Afiyah Pekanbaru. Hasilanalisis faktor yng mempengaruhi penggunaan $\mathrm{KB}$ suntik dapat dilihat pada karakteristikresponden sebagai berikut: 
Tabel 1. Distribusi Frekuensi Analisis Univariat Responden

\begin{tabular}{|c|c|c|}
\hline Variabel & Frekuensi & $\%$ \\
\hline \multicolumn{3}{|l|}{ Pengetahuan } \\
\hline Baik & 40 & 70.2 \\
\hline Kurang & 17 & 29,8 \\
\hline Pendidikan & Frekuensi & $\%$ \\
\hline Tinggi & 43 & 75,4 \\
\hline Rendah & 14 & 24,6 \\
\hline Umur & Frekuensi & $\%$ \\
\hline Resiko & 23 & 40,4 \\
\hline Tidak Beresiko & 34 & 59,6 \\
\hline Media Informasi & Frekuensi & $\%$ \\
\hline Cetak & 27 & 47,4 \\
\hline Elektronik & 30 & 52.6 \\
\hline $\begin{array}{l}\text { Ketersediaan } \\
\text { Alat }\end{array}$ & Frekuensi & $\%$ \\
\hline Tersedia & 38 & 66.7 \\
\hline Tidak Tersedia & 19 & 33,3 \\
\hline $\begin{array}{l}\text { Petugas } \\
\text { Kesehatan }\end{array}$ & Frekuensi & $\%$ \\
\hline Berperan & 25 & 43.9 \\
\hline Tidak Berperan & 32 & 56,1 \\
\hline $\begin{array}{l}\text { Dukungan } \\
\text { Suami }\end{array}$ & Frekuensi & $\%$ \\
\hline Mendukung & 31 & 54.4 \\
\hline $\begin{array}{l}\text { Tidak } \\
\text { Mendukung }\end{array}$ & 26 & 45,6 \\
\hline
\end{tabular}

Berdasarkan tabel diatas diketahui bahwa Mayoritas Responden berpengetahuan baik sebanyak 40 orang dengan 70,2\%. Mayoritas berpendidikan tinggi sebnayak 43 orang dengan $75,4 \%$. Mayoritas tidak beresiko 34 orang dengan 59,6\%. Mayoritas mendapat informasi dari media elektronik 30 orang dengan 52,6\%. Mayoritas Ketersedian alat yang tersedia 38 orang dengan 66,7\%. Mayoritas Petugas Kesehatan tidak Berperan sebanyak 32 orang dengan $56,1 \%$. Mayoritas dukungan suami yang mendukung 31 orang dengan 54,4\%.

\section{B. Analisis Bivariat}

Tabel 1. Analisis Faktor YangMempengaruhi penggunaan Kontrasepsi KB Suntik di Klinik Afiyah Pekanbaru

\begin{tabular}{|c|c|c|c|c|c|c|c|c|}
\hline \multirow{3}{*}{$\begin{array}{c}\text { Variabel } \\
\text { Independen }\end{array}$} & \multicolumn{4}{|c|}{ KB Suntik } & \multirow{3}{*}{$\begin{array}{l}\text { JML } \\
\mathbf{N} \\
\end{array}$} & \multirow{3}{*}{$\begin{array}{l}\% \\
\% \\
\end{array}$} & \multirow[t]{3}{*}{$\boldsymbol{P}$} & \multirow[t]{3}{*}{$O R$} \\
\hline & \multicolumn{2}{|c|}{ Menggunakan } & \multicolumn{2}{|c|}{ Tidak Menggunakan } & & & & \\
\hline & $\mathbf{N}$ & $\%$ & $\mathbf{N}$ & $\%$ & & & & \\
\hline Pengetahuan & & & & & & & .006 & $1.8-21.8$ \\
\hline Baik & 31 & $77.5 \%$ & 9 & $22.5 \%$ & 40 & 100 & & \\
\hline Kurang & 6 & $35,3 \%$ & 11 & $64.7 \%$ & 17 & 100 & & \\
\hline Pendidikan & & & & & & & .006 & $0.58-9.87$ \\
\hline Tinggi & 11 & $78.6 \%$ & 3 & $21.4 \%$ & 14 & 100 & & \\
\hline Rendah & 26 & $60.5 \%$ & 17 & $39.5 \%$ & 43 & 100 & & \\
\hline Umur & & & & & & & .012 & $1.55-16.16$ \\
\hline Resiko & 27 & $79,4 \%$ & 7 & $20,6 \%$ & 34 & 100 & & \\
\hline Tidak Beresiko & 10 & $43,5 \%$ & 13 & $56,6 \%$ & 23 & 100 & & \\
\hline Media & & & & & & & .005 & $1.83-21.25$ \\
\hline Cetak & 12 & $44,4 \%$ & 15 & $55,6 \%$ & 27 & 100 & & \\
\hline elektronik & 25 & $83,3 \%$ & 5 & $16,7 \%$ & 30 & 100 & & \\
\hline Ketersdiaan Alat & & & & & & & .000 & $5.49-262$ \\
\hline Tersedia & 37 & $97,4 \%$ & 1 & $2,6 \%$ & 38 & 100 & & \\
\hline Tdk tersedia & 0 & $0 \%$ & 19 & $100 \%$ & 19 & 100 & & \\
\hline Petugas Kesehatan & & & & & & & .000 & $2.97-73.59$ \\
\hline Berperan & 23 & $92,0 \%$ & 2 & $8,0 \%$ & 25 & 100 & & \\
\hline Tidak Berperan & 14 & $43,8 \%$ & 18 & $56,2 \%$ & 32 & 100 & & \\
\hline Dukungan Suami & & & & & & & .000 & $4.18-74.32$ \\
\hline Mendukung & 28 & $90,3 \%$ & 3 & $9,7 \%$ & 31 & 100 & & \\
\hline Tidak & 9 & 34,6 & 17 & 65,4 & 26 & 100 & & \\
\hline
\end{tabular}




\section{Pengetahuan}

Berdasarkan

hasil

$\mathrm{P}$

ValueBerdasarkan hasil (pvalue $=.006<$ 0,05) dapat dinyatakan Hasil analisis bivariat dengan menggunakan uji chi square diperoleh nilai $p=0,005 \mathrm{yang}$ artinya ada hubungan pengetahuan dengan penggunaan kontrasepsi $\mathrm{KB}$ suntik.

Perilaku seseorang didasari oleh pengetahuan, kesadaran dan sikap positif. Sehingga mempengaruhi perilaku tersebut terhadap wanita usia subur dalam menggunakan alat kontrasepsi KB suntik. Hasil penelitian menunjukkan sebagian besar respondentingkat pengetahuannya tinggi karena sebagian besar responden memahami benar tentang jenis, manfaat, dan cara pemakaian alat kontrasepsi (Bernadus et all,2013)

\section{Pendidikan}

Hasil analisis bivariat dengan menggunakan uji chi square diperoleh nilai $p=.006$ yang artinya ada hubungan tingkat pendidikan aseptor $\mathrm{KB}$ dalam menggunakan KB suntik.

Menurut penelitian yang dilakukan oleh Yustiani (2013) tingkat pendidikan diperlukan untuk mendapatkan informasi misalnya hal-hal yang menunjang kesehatan termasuk hal penggunaan alat kontrasepsi. Tingkat pendidikan yang rendah mempengaruhi pengetahuan seseorang sehingga responden yang berpendidikan rendah akan berkorelasi dengan rendahnya pengetahuan responden tentang alat kontrasepsi (Sunarsih et all, 2015)

\section{Umur}

Hasil analisis bivariat dengan menggunakan uji chi square diperoleh nilai $p=.012$ yang artinya ada hubungan Umur dengan penggunaan KB suntik.

Kematangan usia seseorang mempengaruhi dalam pengambilan keputusan dan proses berfikir dalam menentukan KB yang akan di gunakan. Semakin cukup umur, tingkat kematangan dan kekuatan seseorang akan lebih matang dalam berfikir.

\section{Media Informasi}

Hasil analisis bivariat dengan menggunakan uji chi square diperoleh nilai $p=.005$ yang artinya ada hubungan Media Informasi dengan penggnaan aseptor $\mathrm{KB}$ dalam menggunakan $\mathrm{KB}$ suntik.

Dari beberapa Faktor yang mempngaruhi penggunaan kontrasepsi KB Suntik, Maka Media Informasi yang memiliki nilai $p$ value.005, sehingga media massa mempunyai nilai yang paling sedikit berpengaruh terhadap 
pemilihan kontrasepsi KB suntik di Klinik Pratama Afiyah Pekanbaru.

Hubungan peran media informasi dalam mempengaruhi sikap terhadap keikutsertaan ber-KB, seperti Televisi merupakan media yang paling banyak di lihat oleh masyarakat.

\section{Ketersediaan Alat Kontrasepsi}

Hasil analisis bivariat dengan menggunakan uji chi square diperoleh nilai $p=.000$ yang artinya ada hubungan ketersediaan alat kontrasepsi dengan penggunaan $\mathrm{KB}$ suntik

Dari beberapa Faktor yang mempengaruhi penggunaan kontrasepsi KB Suntik, Maka Ketersediaan Alat Kontrasepsi yang memiliki nilai $p$ value.000, sehingga Ketersediaan Alat Kontrasepsi mempunyai nilai yang paling tinggi berpengaruh terhadap pemilihan kontrasepsi KB suntik diklinik afiyah pekanbaru

\section{Ketersediaan alat kontrasepsi} terwujud dalam bentuk fisik, tersedia atau tidaknya fasilitas atau sarana kesehatan (tempat pelayanan kontrasepsi). Untuk dapat digunakan, pertama kali suatu metode kontrasepsi harus tersedia dan mudah didapat. Promosi metode tersebut melalui media, melalui kontak langsung oleh petugas program $\mathrm{KB}$, oleh dokter dan sebagainya dapat meningkatkan secara nyata pemilihan metode KB.

\section{Petugas Kesehatan}

Hasil analisis bivariat dengan menggunakan uji chi square diperoleh nilai $p=.000$ yang artinya ada hubungan petugas kesehatan dengan penggunaan KB suntik.

Petugas KB seharusnya berperan dalam memberikan konseling, motivasi, dan bimbingan mengenai program $\mathrm{KB}$ yang dapat diikuti akseptor yang salah satunya adalah pemilihan alat kontrasepsi. Perlunya informasi bagi masyarakat dikarenakan dapat membantu kesuksesan dari program KB yang dicanangkan oleh pemerintah.

\section{Dukungan Suami}

Hasil analisis bivariat dengan menggunakan uji chi square diperoleh nilai $p=.000$ yang artinya ada hubungan Dukungan Suami dengan penggunaan KB suntik.

Dukungan membuat keluarga mampu melaksanakan fungsinya, karena anggota keluarga memang seharusnya saling memberikan dukungan dan saling memperhatikan keadaan dan kebutuhan kesehatan istri. Dukungan suami terdiri dari 4 bentuk, yaitu dukungan informasional, penilaian, instrumental, dan emosional. 
Kontrasepsi tidak dapat dipakai istri tanpa adanya kerjasama suami dan saling percaya. Idealnya pasangan suami istri harus memilih metode kontrasepsi yang terbaik, saling bekerjasama dalam pemakaian, membayar biaya pengeluaran untuk kontrasepsi, dan memperhatikan tanda bahaya pemakaian (Hartanto, 2010).

\section{SIMPULAN DAN SARAN}

Analisis Faktor yang mempengaruhi penggunaan kontrsepsi KB Suntik di Klinik Pratama Afiyah Pekanbaru dipengaruhi oleh beberapa factor yaitu; responden dengan berpengetahuan baik 40 orang $(70,2 \%)$, berpendidikan tinggi 43 orang $(75,4 \%)$, berumur tidak beresiko 34 orang $(59,6 \%)$, mendapat informasi dari media elektronik 30 orang $(52,6 \%)$, memilih KB berdasarkan ketersediaan alat 38 orang $(66,7 \%)$, memilih KB berdasarkan peran tugas kesehatan tidak berperan 32 orang (56,1\%), memilih KB berdasarkan dukungan dari Suami 31 orang $(54,4 \%)$.

Saran penulis penelitian ini dapat dijadikan acuan untuk penelitian selnjtnya dan tambahan wawasan bagi responden.

\section{DAFTAR PUSTAKA}

Astuti, DY, 2010. Kontrasepsi Suntik. Diakses dari http://www.ktiskripsi.com/2010/0 5/kti-kb-suntik.html. Pada tanggal 12 Maret 2011.

Bernadus JD, Madianung A, Masi G. 2013. Faktor-Faktor yang Berhubungan dengan Pemilihan Alat Kontrasepsi Dalam Rahim (AKDR) Bagi Akseptor KB di Puskesmas Jailolo. Jurnal $e$ NERS (eNS), Volume 1, Nomor 1, Maret 2013

BKKBN. 2012. Alat Bantu Pengambilan Keputusan Ber-KB. Edisi 8. Jakarta: BKKBN

Gustikawati, D.A. 2014, Faktor Pendukung dan Penghambat Istri PUS dalam Penggunaan Alat Kontrasepsi Implant di Puskesmas 1 Denpasar Utara .Publikas Penelitian. Denpasar: Jurusan Kesehatan Masyarakat Universitas Udaya.

Handayani Sri, 2010, Buku Ajar Keluarga Berencana. Yogyakarta: Pustaka Rihama

Hartanto, H. 2010. KB dan Kontrasepsi. Jakarta: Pustaka Sinar Harapan.

Irianto, K. 2014. Pelayanan Keluarga Berencana Dua Anak Cukup. Bandung: Alfabeta

Sugiyono. 2017. Metode Penelitian Kuantitatif, Kualitatif, dan $R \& D$. Bandung : Alfabeta, CV

Sunarsih, Evrianasari, N \& Damayanti R. 2015. Faktor-faktor yang berhubungan dengan 


\begin{abstract}
penggunaan alat kontrasepsi pada wanita usia subur(WUS) Di

Kelurahan Campang Raya

Bandar Lampung Tahun 2014.
\end{abstract}

